\title{
First description of Trypanosoma cruzi human infection in Esmeraldas province, Ecuador
}

\author{
Ángel Guevara1*, Juan Moreira ${ }^{1,2^{\wedge}}$, Hipatia Criollo', Sandra Vivero', Marcia Racines', Varsovia Cevallos ${ }^{3}$, \\ Rosanna Prandi ${ }^{2}$, Cynthia Caicedo ${ }^{2}$, Francisco Robinzon ${ }^{2}$ and Mariella Anselmi ${ }^{2,4}$
}

\begin{abstract}
Chagas disease was described in Ecuador in 1930 in the province of Guayas and thereafter in various provinces. Triatomine were reported in the province of Esmeraldas but no human infection has been described. Here we report the first evidence that the disease does exist in the province of Esmeraldas. In indigenous Awá communities located in the northwest jungle of the Esmeraldas province, 144 individuals were tested using ELISA and PCR for T.cruzi of which 5 (3.47\%) were positive. Twenty eight triatomine were collected, 27 were Triatoma dispar and 1 Pastrongylus rufotuberculatus, T.cruzi was detected in 11 (42.3\%) of 26 insects.
\end{abstract}

Keywords: Triatoma dispar L, Trypanosoma cruzi, Ecuador, Esmeraldas, Awá population, Chagas disease

\section{Letter}

Chagas disease or American trypanosomiasis, is caused by an infection by the protozoan hemoflagellate Trypanosoma cruzi, which is transmitted to humans through bites of infected triatomine insects. The infection is widespread throughout Latin America although an increasing number of cases in non-endemic countries have been described [1]. In Ecuador, human T.cruzi infections have been observed in different provinces since 1930 [2,3]. However, in the Esmeraldas province, although triatomine insects were reported, autochthonous cases of T.cruzi human infection have not been documented [2]. The province of Esmeraldas, bordering the southern regions of Colombia, is located in the northwest of the country. Most of the inhabitants are of African descendant with dispersed indigenous populations such as the Epera, Chachi and Awá. The latter are also called kwaiker, speak their own language (Awá pit) and live in remote areas, isolated from any urban areas. Reports from individuals from three Awá's villages: Mataje Alto (17 N 0772280, UTM 0134144, $221 \mathrm{~m}$ ), Pambilar (17 N 0766542, UTM 0124494, 144 m) and Balsareño (17 N 0761275, UTM

\footnotetext{
* Correspondence: angel_gustavoguevara@hotmail.com

Deceased

'Laboratorio de Parasitologia Molecular y Medicina Tropical, Centro de Biomedicina, Carrera de Medicina, Universidad Central del Ecuador, Sodiro N14121 e lquique, Quito, Ecuador

Full list of author information is available at the end of the article
}

0128009, $44 \mathrm{~m}$ ) revealed the presence of triatomine insects in their homes and in peridomestic areas. Therefore, a protocol to study insects and human blood of Awá population was prepared and approved by the Bioethics Committee COBI-ASFORUM (Federalwide Assurance FWZ00002482, IEC IORG0001932, IRB00002438, IEPID NPI 125754-12/132854-13) in Quito-Ecuador.

We collected twenty-eight insects and sent them to the laboratory for identification and detection of T.cruzi infection. Twenty-seven of the insects were Triatoma dispar Lent and one was Pastrongylus rufotuberculatus according to conventional taxonomic keys. Since the insects were not optimally preserved, it was impossible to detect living forms of trypanosomes using microscopic techniques. Specific PCR for T.cruzi DNA was performed according to previously described procedures $[4,5]$ in 26 of 28 specimens collected and 11 (42.3\%) were positive (Table 1, Figure 1).

In two Awás villages (Pambilar and Balsareño), 144 blood samples were obtained with informed consent and sera were analyzed for antibodies against T.cruzi utilizing three different serological tests according to manufacturer's instructions. The three different commercial ELISA tests showed high absorbance values indicating a strong anti-T.cruzi IgG response in $5(3.47 \%)$ of 144 
Table 1 Triatomine insects collected in Awá's communities of northwest jungle of Esmeraldas province,

\section{Ecuador}

\begin{tabular}{llll}
\hline Community & No & Species & Habitat \\
\hline Pambilar & 17 & Triatoma dispar & Peridomestic \\
Balsareño & 10 & Triatoma dispar & Domestic \\
Balsareño & 1 & Pastrongylus rufotuberculatus & Domestic \\
\hline
\end{tabular}

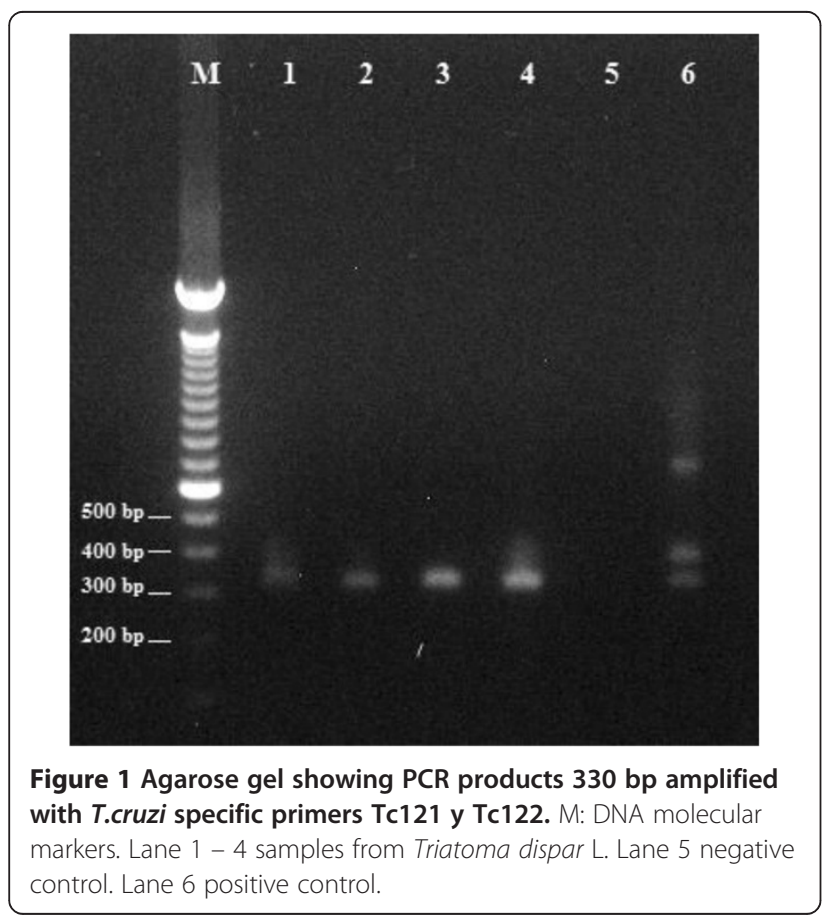

Table 2 Results expressed in absorbance values from human sera samples with three different ELISA tests

\begin{tabular}{llllll}
\hline Sample code & Age & Gender & $\begin{array}{l}\text { Biokit } \\
\text { (ELISA) }\end{array}$ & $\begin{array}{l}\text { Bioschile } \\
\text { (ELISA) }^{\circledR}\end{array}$ & $\begin{array}{l}\text { Chagatest } \\
\text { (ELISA) }^{\oplus}\end{array}$ \\
\hline Pamb 10 & 21 & Male & 1.82 & 1.50 & 0.62 \\
Pamb 12 & 29 & Female & $>2.0$ & $>2.0$ & 2.0 \\
Pamb 18 & 48 & Female & $>2.0$ & $>2.0$ & $>2.0$ \\
Pamb 59 & 62 & Male & 1.84 & 1.96 & 2.0 \\
Bals 37 & 32 & Male & $>2.0$ & $>2.0$ & $>2.0$
\end{tabular}

Cut-off value: Biokit negative $<0.9$; Bioschile negative $<0.9$; Chagatest negative $<0.230$.

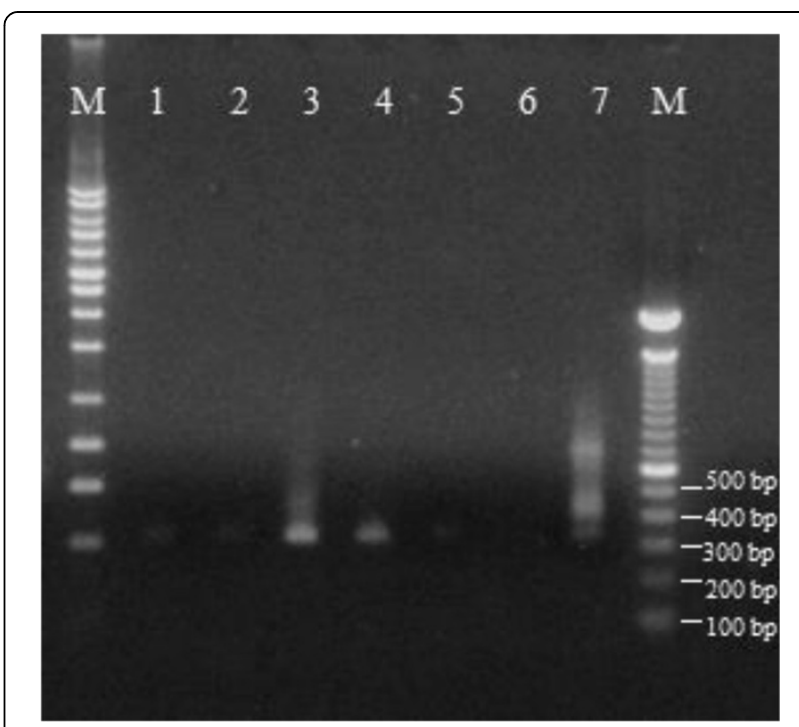

Figure 2 Agarose gel showing PCR products $330 \mathrm{bp}$ amplified with T.cruzi specific primers Tc121 y Tc122. M: DNA molecular markers. Lane 1 - 5 blood samples from Awá infected people. Lane 6 negative control. Lane 7 positive control.

samples tested. T.cruzi specific PCR [6,7] was also positive in all 5 T.cruzi ELISA positive individuals (Table 2, Figure 2).

The present study demonstrates human T.cruzi infection in the northwest jungle of Ecuador. The extent of the infection as well as the associated Chagas disease pathology, if any, in the Awá population remains to be determined. In any case, our findings should alert Ecuadorian health authorities to start an integrated strategy to provide treatment and prevention measures to avoid further transmission. Triatoma dispar Lent is considered as a sylvatic species and has been reported in the northeast jungle of Ecuador [8] but not in the northwest jungle, in this letter 27 (96\%) of 28 triatomine insects collected in northwest province of Esmeraldas were T.dispar $\mathrm{L}$ and many of them were collected in domestic areas. Studies related to vector biology and T.cruzi genotyping in vectors, human beings and wild reservoirs are required to understand the dynamics of T.cruzi transmission in this particular area since triatomine vectors had been shown an ease move from wild to domestic areas [9].

\section{Competing interests}

The authors declare that they have no competing interests.

\section{Authors' contributions}

AG designed the study and wrote the manuscript. HC carried out PCR assays with insects. SV and MR did the serological and PCR tests with humans. RP, CC, FR collected data and samples and socialized the project with communities. VC did the triatominae identification. MA and JM did the protocol for the study, revised the manuscript and search for funding. All authors read and approved the final version of the manuscript. Dr. Juan Moreira passed away on July $14^{\text {th }}$, this article was read and approved by him on early June 2014 


\section{Acknowledgements}

We thank the Federación de Pueblos Awá for their support in the field. Thanks to Ronald Guderian and Thomas Unnasch for critical reviewing of the manuscript.

\section{Author details}

${ }^{1}$ Laboratorio de Parasitologia Molecular y Medicina Tropical, Centro de Biomedicina, Carrera de Medicina, Universidad Central del Ecuador, Sodiro N14121 e lquique, Quito, Ecuador. ${ }^{2}$ CECOMET, Nelson Estupiñan Bass 210 y Luis Tello, Esmeraldas, Ecuador. ${ }^{3}$ Instituto Nacional de Investigación en Salud Pública, Entomología, Ministerio de Salud del Ecuador, Sodiro y Yaguachi, Quito, Ecuador. ${ }^{4}$ Centro de Enfermedades Tropicales, Hospital Sacro Cuore, Verona, Negrar, Italia.

Received: 12 June 2014 Accepted: 16 July 2014

Published: 6 August 2014

\section{References}

1. Bonney K: Chagas disease in the 21st century: a public health success or an emerging threat? Parasite 2014, 21:11.

2. Aguilar M, Abad-Franch F, Racines J, Paucar A: Epidemiology of Chagas disease in Ecuador. A brief review. Mem Inst Oswaldo Cruz 1999, 94:387-393.

3. Arteaga C: Investigaciones sobre la existencia de la enfermedad de Chagas en la zona del ferrocarril de la Costa (Provincia del Guayas). Rev Univ Guayaquil 1930, 1:89-101.

4. Guevara A, Garzón E, Bowen C, Córdova X, Gómez E, Ouaissi A: High infection rates of Triatoma dimidiata are associated with low levels of Trypanosoma cruzi seroprevalence in Pedro Carbo, Ecuador: Use of a tc24 gene-based PCR approach. Parasite 2005, 12:65-68.

5. Smith B, Conlan C, Hwang W, Weirauch C: Polymerase Chain Reaction Detection of Trypanosoma cruzi in Suboptimally Preserved Vectors and Comparative Infection Rates 2007-2010 in Escondido Southern California. Vector-Borne Zoonotic Dis 2011, 11(12):1603-1604.

6. Guevara A, Eras J, Recalde M, Vinueza L, Cooper P, Ouassi A, Guderian R: Severe digestive pathology associated with chronic Chagas disease in Ecuador: report of two cases. Rev Soc Bras Med Trop 1997, 30:389-392.

7. Kirchhoff L, Votava J, Ochs D, Moser D: Comparison of PCR and microscopic methods for detecting Trypanosoma cruzi. J Clin Microb 1996, 34(5):1171-1175

8. Zeledon R, Ugalde J, Paniagua L: Entomological and Ecological Aspects of Six Sylvatic Species of Triatomines (Hemiptera, Reduviidae) from the Collection of the National Biodiversity Institute of Costa Rica, Central America. Mem Inst Oswaldo Cruz Rio de Janeiro 2001, 96(6):757-764.

9. Grijalva M, Villacís A, Ocaña S, Yumiseva C, Baus E: Limitations of selective deltamethrin application for triatomine control in central coastal Ecuador. Parasites \& Vectors 2011, 4:20.

doi:10.1186/1756-3305-7-358

Cite this article as: Guevara et al.: First description of Trypanosoma cruzi human infection in Esmeraldas province, Ecuador. Parasites \& Vectors 2014 7:358.

\section{Submit your next manuscript to BioMed Central and take full advantage of:}

- Convenient online submission

- Thorough peer review

- No space constraints or color figure charges

- Immediate publication on acceptance

- Inclusion in PubMed, CAS, Scopus and Google Scholar

- Research which is freely available for redistribution 